WHEN FRANCE FELL 



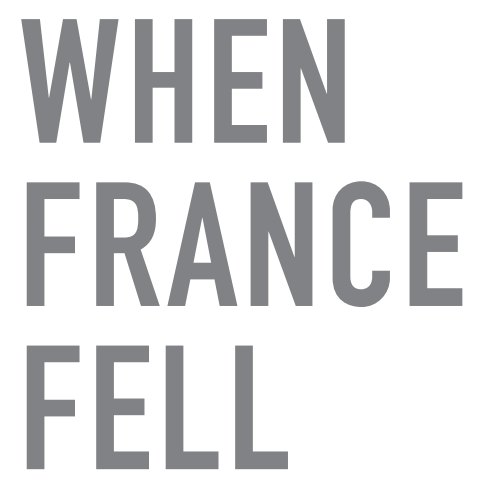

\section{THE VICHY CRISIS}

AND THE FATE OF THE

ANGLO-AMERICAN

ALLIANCE

MICHAEL S. NEIBERG

II Harvard University Press

CAMBRIDGE, MASSACHUSETTS

LONDON, ENGLAND | 2021 
Copyright (C) 2021 by Michael S. Neiberg

All rights reserved

Printed in the United States of America

First printing

Publication of this book has been supported through the generous

provisions of the Maurice and Lula Bradley Smith Memorial Fund.

Cover design: Matt Avery / Monograph Studios

Cover photographs of General Dwight D. Eisenhower and General

Honore Giraud in Algiers, 1943, courtesy of the U.S. Office of War

Information, Library of Congress.

9780674270107 (EPUB)

9780674270114 (PDF)

The Library of Congress has cataloged the printed edition as follows:

Names: Neiberg, Michael S., author.

Title: When France fell : the Vichy crisis and the fate of the

Anglo-American alliance / Michael S. Neiberg.

Description: Cambridge, Massachusetts : Harvard University Press,

2021. Includes bibliographical references and index.

Identifiers: LCCN 2021010189 | ISBN 9780674258563 (cloth)

Subjects: LCSH: France—History_German occupation, 1940-1945. |

France-Politics and government-1940-1945. | United States-

Foreign relations_-France. | France-Foreign relations_-United

States. | United States_-Foreign relations_-Great Britain. | Great

Britain-Foreign relations_-United States. | United States-

Foreign relations - 20th century.

Classification: LCC DC397 .N43 2021 | DDC 940.53/22730944—dc23

LC record available at https://lccn.loc.gov/2021010189 
To Geoff Megargee 
